\title{
Indium In 111 Daclizumab
}

National Cancer Institute

\section{Source}

National Cancer Institute. Indium In 111 Daclizumab. NCI Thesaurus. Code C29230.

A radioimmunoconjug ate comprised of daclizumab, a recombinant humanized monoclonal antibody directed against the alpha subunit of the interleukin-2 (IL-2) receptor (IL-2RA, TAC antigen, CD25), which is labeled with the gamma-emitting isotope indium 111 (In 111; 111/n), with potential radioimag ing application. Upon administration, indium In 111 daclizumab targets and binds to IL-2RA and inhibits the binding of IL-2, thereby blocking IL-2-mediated activation of lymphocytes. IL-2RA is not expressed by normal resting lymphoid cells, with the exception of regulatory T-cells (Tregs), but it is expressed on a minority of Reed-Sternberg cells and, is overexpressed on T-cells rosetting around Reed-Sternberg cells in certain lymphomas. The use of gamma scintigraphy permits the immunodetection of IL-2RA expressing cells. 